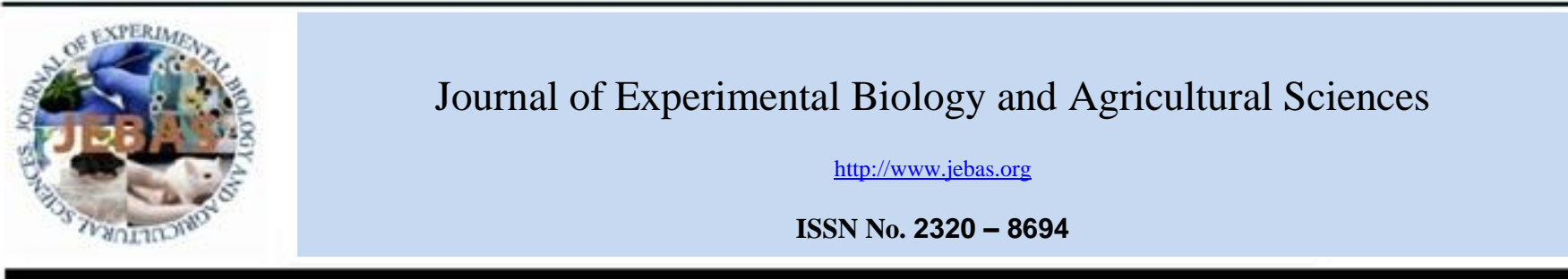

\title{
ASSESSMENT OF MORPHOLOGICAL AND MOLECULAR VARIABILITY AMONG DIFFERENT ISOLATES OF Trichoderma
}

\author{
Purnima Singh ${ }^{1}$, Ashwini Kumar ${ }^{1}$, Yogendra Singh $^{2}$, Subhash Kumar Mishra $^{3}$, Bhumesh Kumar $^{3}$ \\ ${ }^{1}$ Department of Plant Pathology, Jawaharlal Nehru Krishi Viswa Vidyalaya, Jabalpur, Madhya Pradesh, India \\ ${ }^{2}$ Department of Biotechnology, Jawaharlal Nehru Krishi Viswa Vidyalaya, Jabalpur, Madhya Pradesh, India \\ ${ }^{3}$ ICAR- Directorate of Weed Research, Jabalpur, Madhya Pradesh, India
}

Received - November 12, 2019; Revision - December 28, 2019; Accepted - February 11, 2020

Available Online - February 25, 2020

DOI: http://dx.doi.org/10.18006/2020.8(1).41.47

KEYWORDS
Trichoderma
Variability
DNA
Genetic marker
RAPD

\begin{abstract}
The Trichoderma sp. has been recognized as potential biocontrol agent against soil borne pathogen since ages. In present study efforts have been made to identify variability in local isolates of Trichoderma. In total twenty isolates of Trichoderma sp. were collected from different host and locations of Jabalpur from rhizosphere of different crops. The isolates exhibited significant morphological and molecular variability. Under morphological characterization, different isolates of Trichoderma represented different colony colour (white to green), shape of conidia (globose, sub-globose and ellipsoid) and pattern of conidiation (either formation of ring or no ring formation). Another analysis was made to done molecular characterization of twenty isolates of Trichoderma using 13 RAPD primers. Out of 13 RAPD primers, only six primers were found to be polymorphic. A dendrogram was generated by Cluster analysis using UPGMA based on Jaccar'd similarity coefficient. Trichderma isolates were grouped into two clusters i.e. major and minor. Major cluster comprised of 16 genotype that divided into two sub clusters. First sub cluster comprised 12 genotypes while second sub cluster contained 4 genotypes. Minor cluster contained only four genotypes. Results of this study revealed that molecular diversity among different isolates of Trichoderma isolate may or may not be dependent on geographical locations as well as on their colony pattern and colour.
\end{abstract}

* Corresponding author

E-mail: purnimasingh2392@gmail.com (Purnima Singh)

Peer review under responsibility of Journal of Experimental Biology and Agricultural Sciences.

Production and Hosting by Horizon Publisher India [HPI] (http://www.horizonpublisherindia.in/).

All rights reserved.
All the articles published by Journal of Experimental Biology and Agricultural Sciences are licensed under a Creative Commons Attribution-NonCommercial 4.0 International License Based on a work at www.jebas.org.

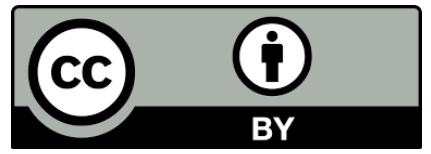




\section{Introduction}

Trichoderma, commonly present in soil and root ecosystems, this genus has gained immense importance since last few decades due to its biological control ability against several plant pathogens (Harman, 2000). Trichoderma harzianum and T. viride are efficient biocontrol agents and these have ability to inhibit growth of pathogen in soil, and improving the overall health of the plant. Further, Trichoderma has ability to reduce growth of pathogens by different mechanisms like competition, antibiosis, mycoparasitism, hyphal interactions, and enzyme secretion. Such microorganisms are now available commercially and are used in crop management and practices (Singh \& Joshi, 2007). Various Trichoderma isolates can be differentiated by mycelial growth rate and colony appearance, as well as microscopic morphological features, including phialides and phialospores. The current technology available makes it possible that different isolates can be distinguished by randomly amplified polymorphic DNA PCR (RAPD-PCR). Restriction fragment length polymorphisms in mitochondrial and ribosomal DNA and sequence analysis of ribosomal DNA (Dodd et al., 2004) has been well documentation. Molecular characterization of the potential biocontrol agents using random amplified polymorphic DNA (RAPD) helps to determine the diversity.

The molecular analysis of several strains revealed that the classification based on morphological data had been a great extent, erroneous resulting in re-classification of several isolates and species (Meyer et al., 1993; Kuhls et al., 1997). The use of molecular markers has given a boost to the analysis of the accurate variation among various isolates of these bioagents. Latha et al. (2002) reported that the RAPD (random amplified polymorphic DNA) techniques can be used for distinguishing strains of bioagents. By using the RAPD procedure (Williams et al., 1990), which incorporates the PCR (polymerase chain reaction) technique without depending on a known DNA sequence, information can be generated on amplification patterns from only a small amount of DNA. The present research work was undertaken to determine morphological and genetic variations among the isolates of Trichoderma spp. obtained from rhizosphere regions of different Plant by using RAPD marker.

\section{Materials and Methods}

\subsection{Collection, Isolation, Purification and identification of Trichoderma isolates}

Twenty soil samples were collected from rhizosphere of different plants from Jabalpur (Table 1). Isolation of Trichoderma from collected soil sample was done by serial dilution method. The cultures were identified on the basis of colony colour, branching pattern of conidiophores, shape of phialides, and emergence of phialides and spore characters (Gams \& Bisset, 1998)
Table 1 Collection site and crop for different Trichoderma isolates

\begin{tabular}{|c|c|c|c|}
\hline S.No. & Isolate code & Crop & Location \\
\hline 1 & $\mathrm{~T}_{1}$ & Red gram & Forestry field \\
\hline 2 & $\mathrm{~T}_{2}$ & Green gram & Talab area \\
\hline 3 & $\mathrm{~T}_{3}$ & Soybean & Dusty area \\
\hline 4 & $\mathrm{~T}_{4}$ & Soybean & IFS, college campus \\
\hline 5 & $\mathrm{~T}_{5}$ & Maize & Adhartal \\
\hline 6 & $\mathrm{~T}_{6}$ & Soybean & Farmer's field \\
\hline 7 & $\mathrm{~T}_{7}$ & Rice & Farmer's field \\
\hline 8 & $\mathrm{~T}_{8}$ & Chilli & Maharajpur \\
\hline 9 & $\mathrm{~T}_{9}$ & Mango & Iemalia \\
\hline 10 & $\mathrm{~T}_{10}$ & Rice & Soil science field \\
\hline 11 & $\mathrm{~T}_{11}$ & Rice & BSP, field \\
\hline 12 & $\mathrm{~T}_{12}$ & Neem & Iemalia \\
\hline 13 & $\mathrm{~T}_{13}$ & Banana & Iemalia \\
\hline 14 & $\mathrm{~T}_{14}$ & Rice & IFS, college campus \\
\hline 15 & $\mathrm{~T}_{15}$ & Betelvine & College campus \\
\hline 16 & $\mathrm{~T}_{16}$ & Soybean & BSP,field \\
\hline 17 & $\mathrm{~T}_{17}$ & Okra & Maharajpur \\
\hline 18 & $\mathrm{~T}_{18}$ & Soybean & BSP,field \\
\hline 19 & $\mathrm{~T}_{19}$ & Okra & Horticulture field \\
\hline 20 & $\mathrm{~T}_{20}$ & Citrus & Sehora \\
\hline
\end{tabular}

\subsection{Morphological variability}

Growth characteristics of Trichoderma isolates obtained from different locations were studied on PDA medium. Morphological characteristics such as colony growth, colour, reverse side colony colour and condition for each isolate were noted. The observations were recorded up to seven days at $24 \mathrm{hrs}$ interval.

\subsection{Fungal multiplication}

Potato dextrose broth (PDB) was used to get mycelial growth of fungus for extraction of DNA. Each flask was inoculated with 6 $\mathrm{mm}$ mycelial disc of the fungus. The inoculated flasks were incubated for 10 days at $28+1{ }^{\circ} \mathrm{C}$ in BOD incubator. At the end of incubation period, the mycelial mats were harvested by filtering through whatman paper no. 1 filter paper, washed with sterilized water thrice, blot dried and stored in Aluminium-foils at $-20^{\circ} \mathrm{C}$.

\subsection{Molecular elucidation}

Genomic DNA was isolated using Saghai-Marrof et al. (1984) method with some modifications. For DNA extraction, Trichoderma 
spp. samples (mycelial mats) were crushed in liquid nitrogen using pestle mortar. Quality and quantity of extracted genomic DNA was assessed by UV-spectrophotometer (DS 11+, DeNovix) and submerged horizontal electrophoresis using agarose gel $(0.8 \%)$.

Polymerase chain reaction (PCR) amplifications were performed in a programmable thermocycler (Takara). Each sample was amplified in a reaction mixture containing $50 \mathrm{ng}$ genomic DNA, 1 unit of Taq polymerase (New England Biolabs), 10x PCR buffer with $2.5 \mathrm{mM}$ $\mathrm{MgCl} 2$ and $200 \mu \mathrm{M}$ of each dNTP (New England Biolabs), 10 pmol of 10-mer RAPD primers (Operon Technologies, USA). The cycling parameters for RAOD were adjusted as to provide first denaturation for 5 minutes at $94^{\circ} \mathrm{C}$ followed by 45 cycles of 1 minute each at 94 and $37^{\circ} \mathrm{C}$ followed by 2 minute at $72^{\circ} \mathrm{C}$ and final extension for 5 minutes at same temperature. After the final extension process products were cooling to $4{ }^{\circ} \mathrm{C}$, amplified PCR products were stored at $4{ }^{\circ} \mathrm{C}$ until electrophoresis. Amplified products were separated on $1.5 \%$ agarose gel to determine the size of amplified DNA fragments. Polymerase chain reactions were repeated thrice to confirm reproducibility of primers. Reproducible bands were scored manually as ' 1 ' or ' 0 ' for presence or absence of the bands. The final RAPD data was used to calculate genetic similarity measured by Jacard similarity coefficient based NTSYS-PC version 1.8 (Exeter Software, Setauket, NY, U. S A.) software package (Rohlf, 2002). Cluster analysis was performed and constructing dendrogram using the unweighted pair group method with arithmetic average (UPGMA) (Sneath \& Sokal, 1973)

\section{Results and Discussion}

\subsection{Morphological characterization}

Morphological characteristics comprising growth rate, colony colour and colony appearance were examined. According to Samules et al. (2002) these characteristics are very important in identification and classification of genus Trichoderma. In present study, morphological characteristics of twenty isolate of Trichoderma species are presented in Table 2. Colony characteristics were observed for their growth type, colony edge, and colony colour after five days of incubation at $25^{\circ} \mathrm{C}$. Production of secondary metabolite or antibiotic was also observed by colour production on backside of petriplate after 5 days of growth. Regular circular growth of Trichoderma isolate was observed on PDA. Colony growth pattern varied as submerged, cottony and fluffy. However, most of the colonies were submerged type. Isolated Trichoderma colonies showed different colour like white $\left(\mathrm{T}_{1}, \mathrm{~T}_{2}, \mathrm{~T}_{6}, \mathrm{~T}_{11}, \mathrm{~T}_{14}, \mathrm{~T}_{17}\right.$ and $\left.\mathrm{T}_{20}\right)$, yellowish white $\left(T_{8}, T_{15}\right.$ and $\left.T_{19}\right)$, whitish green/light green $\left(T_{5}, T_{7}, T_{13}, T_{14}\right.$ and $\left.T_{16}\right)$, olive green $\left(T_{3}, T_{9}\right.$ and $\left.T_{18}\right)$ and dark green $\left(T_{10}\right)$. Eleven isolates produced buff yellow $\left(T_{1}, T_{2}, T_{5}, T_{6}, T_{10}, T_{11}, T_{15}, T_{16}, T_{17}\right.$ and $\left.T_{19}\right)$ colour as observed from reverse side, remaining isolates exhibited white $\left(\mathrm{T}_{7}, \mathrm{~T}_{8}, \mathrm{~T}_{14}\right.$ and $\left.\mathrm{T}_{20}\right)$, light green $\left(\mathrm{T}_{3}, \mathrm{~T}_{9}\right.$ and $\left.\mathrm{T}_{18}\right)$ and dark green $\left(T_{12}\right.$ and $\left.T_{13}\right)$. Slide were prepared for various isolated and observed under microscope, result of microscope observations revealed that the phialides shape varied from ampuliform, lageniform and cylindrical. Further, shape of conidia was also observed and it varies from sub-globose to ellipsoidal, whereas conidia colour were reported hyaline to green. The present findings are in agreement with the results reported by Gams \& Bisset (1998) and Tomar et al. (2017).

In view of the present study, initially 13 RAPD primers were screened from 20 isolate of Trichoderma species. Six RAPD primers that produced consistently strong amplification products (Figure 1) and polymorphic banding patterns were selected for further interpretation of analysis. In consequence, selected six RAPD primers (Table 3) amplified a total of 26 loci. The band size of amplified fragments ranged from 100-2200bp. Out of 26 bands amplified, 8 were found to be monomorphic (30.7\%) and remaining 18 were polymorphic (69.2\%). The average number of bands per primer was (4.3) while number of polymorphic bands

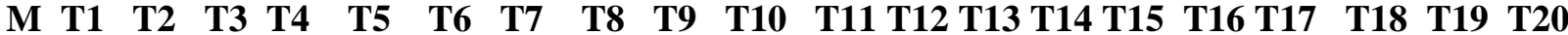
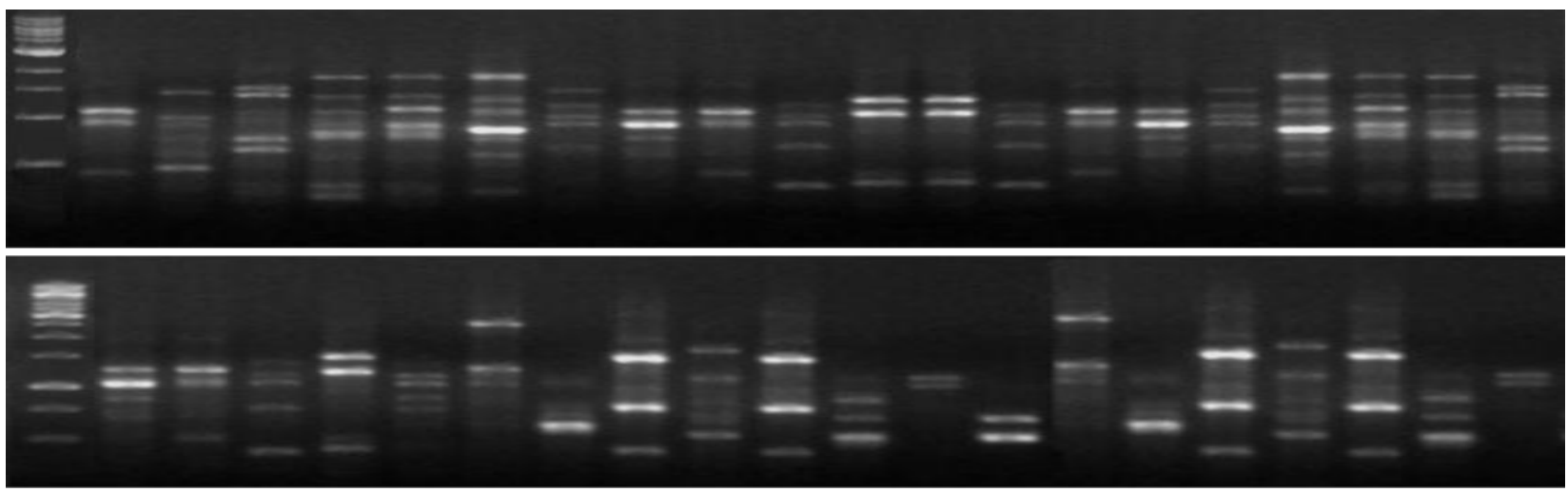

Figure 1 RAPD electrophoretic banding pattern of different isolate of Trichoderma using OPA-02 and OPA-16. (M: Ladder; T1-T20 isolates of Trichoderma)

Journal of Experimental Biology and Agricultural Sciences http://www.jebas.org 
Table 2 Morphological characteristic of twenty isolates of Trichoderma grown on PDA at $25 \pm 2{ }^{\circ} \mathrm{C}$

\begin{tabular}{|c|c|c|c|c|c|c|c|c|}
\hline \multirow{2}{*}{$\begin{array}{l}\text { Isolate } \\
\text { code }\end{array}$} & \multirow{2}{*}{$\begin{array}{l}\text { Type of } \\
\text { growth }\end{array}$} & \multicolumn{2}{|c|}{ Colony colour } & \multirow{2}{*}{$\begin{array}{l}\text { Colony } \\
\text { edge }\end{array}$} & \multirow[t]{2}{*}{ Conidiation } & \multirow[t]{2}{*}{ Phialides shape } & \multicolumn{2}{|c|}{ Conidia } \\
\hline & & Upper & Reverse & & & & Shape & Colour \\
\hline $\mathrm{T}_{1}$ & Submerged & White & Buff yellow & Smooth & $\begin{array}{l}\text { No ring } \\
\text { formation }\end{array}$ & Lageniform & $\begin{array}{l}\text { Ovoid to } \\
\text { ellipsoid }\end{array}$ & Hyaline \\
\hline $\mathrm{T}_{2}$ & Submerged & White & Buff yellow & Smooth & $\begin{array}{l}\text { No ring } \\
\text { formation }\end{array}$ & Lageniform & $\begin{array}{l}\text { Ovoid to } \\
\text { ellipsoid }\end{array}$ & Hyaline \\
\hline $\mathrm{T}_{3}$ & Cottony & Olive green & Light green & Smooth & $\begin{array}{c}\text { No ring } \\
\text { formation }\end{array}$ & $\begin{array}{c}\text { Ampulliform to } \\
\text { lageniform }\end{array}$ & $\begin{array}{c}\text { Sub-globose to } \\
\text { ovoid }\end{array}$ & Green \\
\hline $\mathrm{T}_{4}$ & Submerged & $\begin{array}{l}\text { Yellowish } \\
\text { green }\end{array}$ & Buff yellow & Smooth & $\begin{array}{c}\text { No ring } \\
\text { formation }\end{array}$ & Cylindrical & Sub- globose & Green \\
\hline $\mathrm{T}_{5}$ & Cottony & Light green & Buff yellow & Smooth & $\begin{array}{c}\text { Ring } \\
\text { formation }\end{array}$ & Ampuliform & Ellipsoid & Hyaline \\
\hline $\mathrm{T}_{6}$ & Submerged & White & Buff yellow & Smooth & $\begin{array}{l}\text { No ring } \\
\text { formation }\end{array}$ & Ampulliform & Ellipsoid & Hyaline \\
\hline $\mathrm{T}_{7}$ & Submerged & Light green & White & Smooth & $\begin{array}{c}\text { No ring } \\
\text { formation }\end{array}$ & Lageniform & Globose & Hyaline \\
\hline $\mathrm{T}_{8}$ & Submerged & White & White & Smooth & $\begin{array}{l}\text { No ring } \\
\text { formation }\end{array}$ & Cylindrical & Globose & Green \\
\hline $\mathrm{T}_{9}$ & Fluffy & $\begin{array}{l}\text { Olive } \\
\text { green }\end{array}$ & Light green & Smooth & $\begin{array}{c}\text { Ring } \\
\text { formation }\end{array}$ & Lageniform & $\begin{array}{c}\text { Globose to } \\
\text { ellipsoid }\end{array}$ & Green \\
\hline $\mathrm{T}_{10}$ & Fluffy & Dark Green & $\begin{array}{l}\text { Buff Yellow with } \\
\text { olive green rings }\end{array}$ & Smooth & $\begin{array}{c}\text { Ring } \\
\text { formation }\end{array}$ & Lageniform & Ellipsoid & Green \\
\hline $\mathrm{T}_{11}$ & Cottony & Green & Buff Yellow & Smooth & $\begin{array}{c}\text { Ring } \\
\text { formation }\end{array}$ & Cylindrical & Ellipsoid & Green \\
\hline $\mathrm{T}_{12}$ & $\begin{array}{c}\text { Compact/ } \\
\text { fluffy }\end{array}$ & $\begin{array}{l}\text { Whitish } \\
\text { green }\end{array}$ & Dark green & Smooth & $\begin{array}{c}\text { Ring } \\
\text { formation }\end{array}$ & Lageniform & $\begin{array}{c}\text { Ellipsoid- } \\
\text { ovoid }\end{array}$ & Green \\
\hline $\mathrm{T}_{13}$ & $\begin{array}{c}\text { Compact/ } \\
\text { fluffy }\end{array}$ & $\begin{array}{c}\text { Whitish } \\
\text { green }\end{array}$ & Dark green & Smooth & $\begin{array}{c}\text { Ring } \\
\text { formation }\end{array}$ & Lageniform & $\begin{array}{c}\text { Subglobose to } \\
\text { ovoid }\end{array}$ & Green \\
\hline $\mathrm{T}_{14}$ & Submerged & White & White & Smooth & $\begin{array}{c}\text { No ring } \\
\text { formation }\end{array}$ & Cylindrical & Sub- globose & Green \\
\hline $\mathrm{T}_{15}$ & Submerged & $\begin{array}{l}\text { Yellowish } \\
\text { white }\end{array}$ & Buff yellow & Smooth & $\begin{array}{c}\text { No ring } \\
\text { formation }\end{array}$ & Ampulliform & Globose & Hyaline \\
\hline $\mathrm{T}_{16}$ & $\begin{array}{c}\text { Compact/ } \\
\text { Fluffy }\end{array}$ & $\begin{array}{l}\text { Whitish } \\
\text { green }\end{array}$ & $\begin{array}{l}\text { Buff Yellow with } \\
\text { olive green rings }\end{array}$ & Smooth & $\begin{array}{c}\text { Ring } \\
\text { formation }\end{array}$ & Lageniform & Ellipsoid & Green \\
\hline $\mathrm{T}_{17}$ & Submerged & White & Buff Yellow & Smooth & $\begin{array}{c}\text { Ring } \\
\text { formation }\end{array}$ & Cylindrical & Sub- globose & Hyaline \\
\hline $\mathrm{T}_{18}$ & Cottony & $\begin{array}{l}\text { Olive } \\
\text { green }\end{array}$ & Light green & Smooth & $\begin{array}{c}\text { No ring } \\
\text { formation }\end{array}$ & Ampulliform & Globose & Hyaline \\
\hline $\mathrm{T}_{19}$ & Cottony & $\begin{array}{l}\text { Yellowish } \\
\text { White }\end{array}$ & Buff yellow & $\begin{array}{l}\text { Smooth } \\
\text { compact }\end{array}$ & $\begin{array}{c}\text { No ring } \\
\text { formation }\end{array}$ & Ampulliform & Globose & Hyaline \\
\hline $\mathrm{T}_{20}$ & Submerged & White & White & Smooth & $\begin{array}{c}\text { No ring } \\
\text { formation }\end{array}$ & Lageniform & Ellipsoid & Hyaline \\
\hline
\end{tabular}

Table 3 RAPD primers used for molecular diversity analysis in different genotypes of Trichoderma isolate

\begin{tabular}{|c|c|c|c|c|c|c|}
\hline S.No & Primer & Sequences 5'- 3' & $\mathrm{GC}(\%)$ & TB & PB & PP \\
\hline 1 & OPA-02 & 5'-TGCCGAGCTG-3' & 70 & 6 & 4 & 66.6 \\
\hline 2 & OPA-04 & 5'-AATCGGGCTG-3' & 60 & 4 & 3 & 75 \\
\hline 3 & OPA-05 & 5'-AGGGGTCTTG-3' & 60 & 3 & 2 & 66.6 \\
\hline 4 & OPA-06 & 5'-GGTCCCTGAC-3' & 70 & 5 & 3 & 60 \\
\hline 5 & OPA-12 & 5'-TCGGCGATAG-3' & 60 & 4 & 3 & 75.0 \\
\hline \multirow[t]{2}{*}{6} & OPA-16 & 5'-AGCCAGCGAA-3' & 60 & 4 & 3 & 75.0 \\
\hline & \multicolumn{3}{|c|}{ Total (average) } & $26(4.3)$ & $18(3)$ & 69.7 \\
\hline
\end{tabular}

TB: Total band; PB: Polymorphic bands; PP: Percentage of polymorphism 
per primer was 3. Maximum numbers of bands (6) were scored by primer OPA- 02 while minimum numbers of bands (3) were scored by primer OPA-05. Banding patterns achieved by 6 best performing primers (OPA-02 and OPA-16) have been presented in Figure 1.

The similarity coefficient values were obtained after multivariate analysis using jaccard's value. These similarity coefficient values were used to construct a dendrogram by UPGMA method (Figure 2). Cluster analysis revealed that species of Trichoderma isolates under study divided into two groups, major group and minor group. Major group comprised 16 genotypes that divided into two sub groups. First subgroup contained 12 genotypes $\mathrm{T}_{1}, \mathrm{~T}_{5}, \mathrm{~T}_{6}, \mathrm{~T}_{8}$, $\mathrm{T}_{12}, \mathrm{~T}_{14}, \mathrm{~T}_{15}, \mathrm{~T}_{16}, \mathrm{~T}_{17}, \mathrm{~T}_{18}, \mathrm{~T}_{19}$ and $\mathrm{T}_{20}$ while second subgroup contained 4 genotypes $T_{2}, T_{4}, T_{11}$ and $T_{13}$. Minor group contained only four genotypes namely $T_{3}, T_{7}, T_{9}$ and $T_{10}$. Among the genotypes, $T_{9}$ and $T_{12}$ collected from two very closely located place (from Iemalia) placed at distantly while genotypes collected from distant locations i.e. from Iemalia $\left(T_{12}\right)$ and Sehora $\left(T_{20}\right)$ groped into same cluster. Similarly, genotypes isolated from IFS college campus $\left(\mathrm{T}_{14}\right)$ and Maharajpur $\left(\mathrm{T}_{17}\right)$ placed into same cluster. Results of this study clearly indicate that molecular diversity among different genotypes of Trichoderma isolate may or may not be dependent on geographically locations. Apart from this interpretation, according to dendrogram that resulted in segregation of 2 clusters i.e. major and minor. Cluster 1 (major) was further sub-divided into two sub-clusters, which includes 16 isolates and their colony colour varied from white to olive green. In case of cluster-2 (minor) contains four isolates of Trichoderma which were light green to dark green colour. Another validation of this molecular variability among different Trichoderma isolate may possible or not be depend on their colony pattern or colour. Further, 2-dimensional and 3dimensional scaling further elaborates the clustering pattern at more precise level and supported the results obtained by UPGMA clustering (Figure $3 \& 4$ ). Results of current study are also in agreement with the findings of Williams et al. (1990), Miller \& Tankesly (1990), Dodd et al. (2004), Tripathi et al. (2013), Sharma et al. (2009) and Chakraborthy et al. (2010). Results of study revealed genetic variation at DNA level in various fungi including Trichoderma, also RAPD markers allows estimation of degree of relatedness between individuals.

\section{Conclusion}

In the present investigation 20 isolates of Trichoderma were collected from rhizospheric zone of different crops. All isolates of

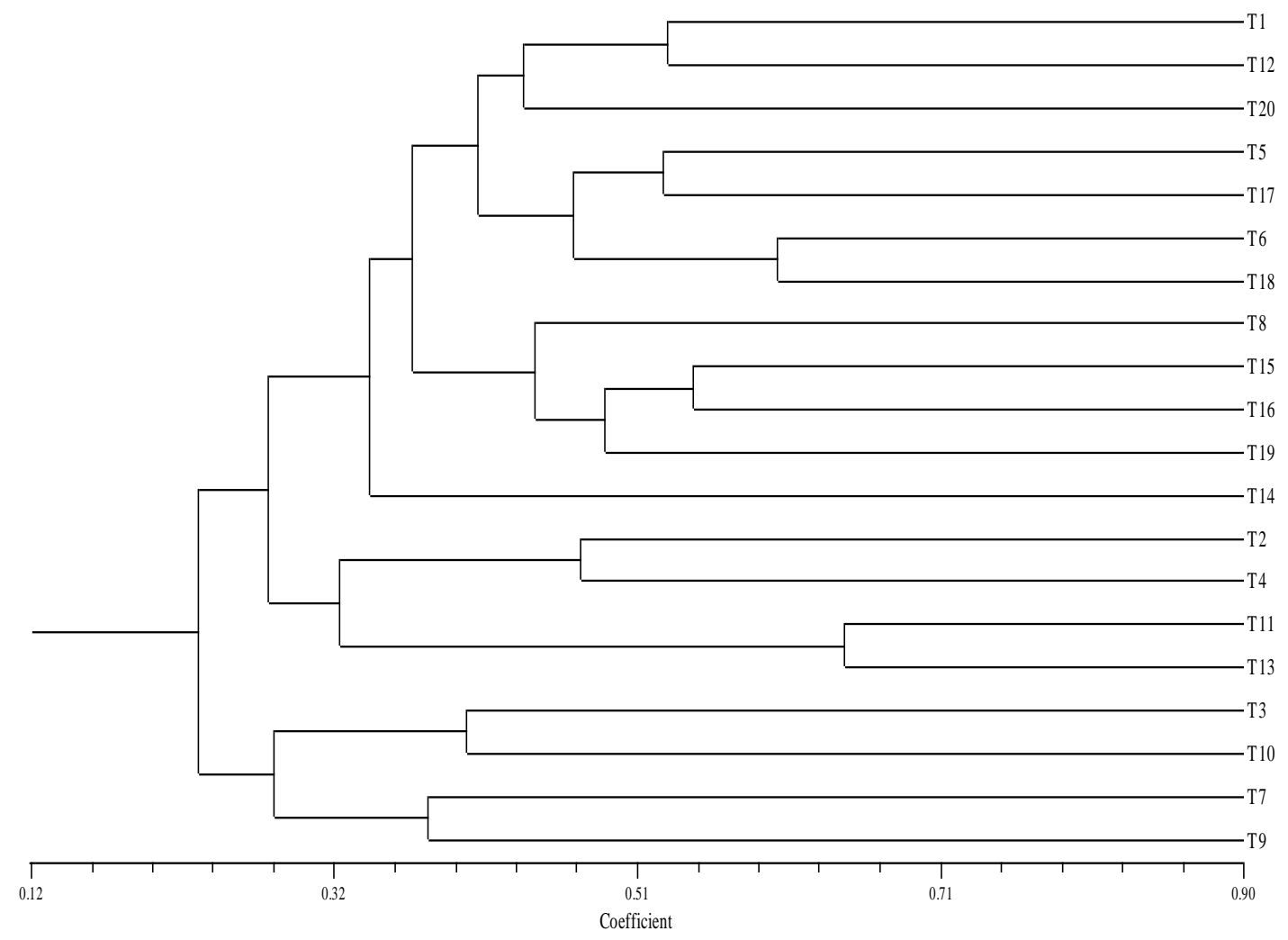

Figure 2 UPGMA clustering among Trichoderma isolate based on RAPD data

Journal of Experimental Biology and Agricultural Sciences http://www.jebas.org 


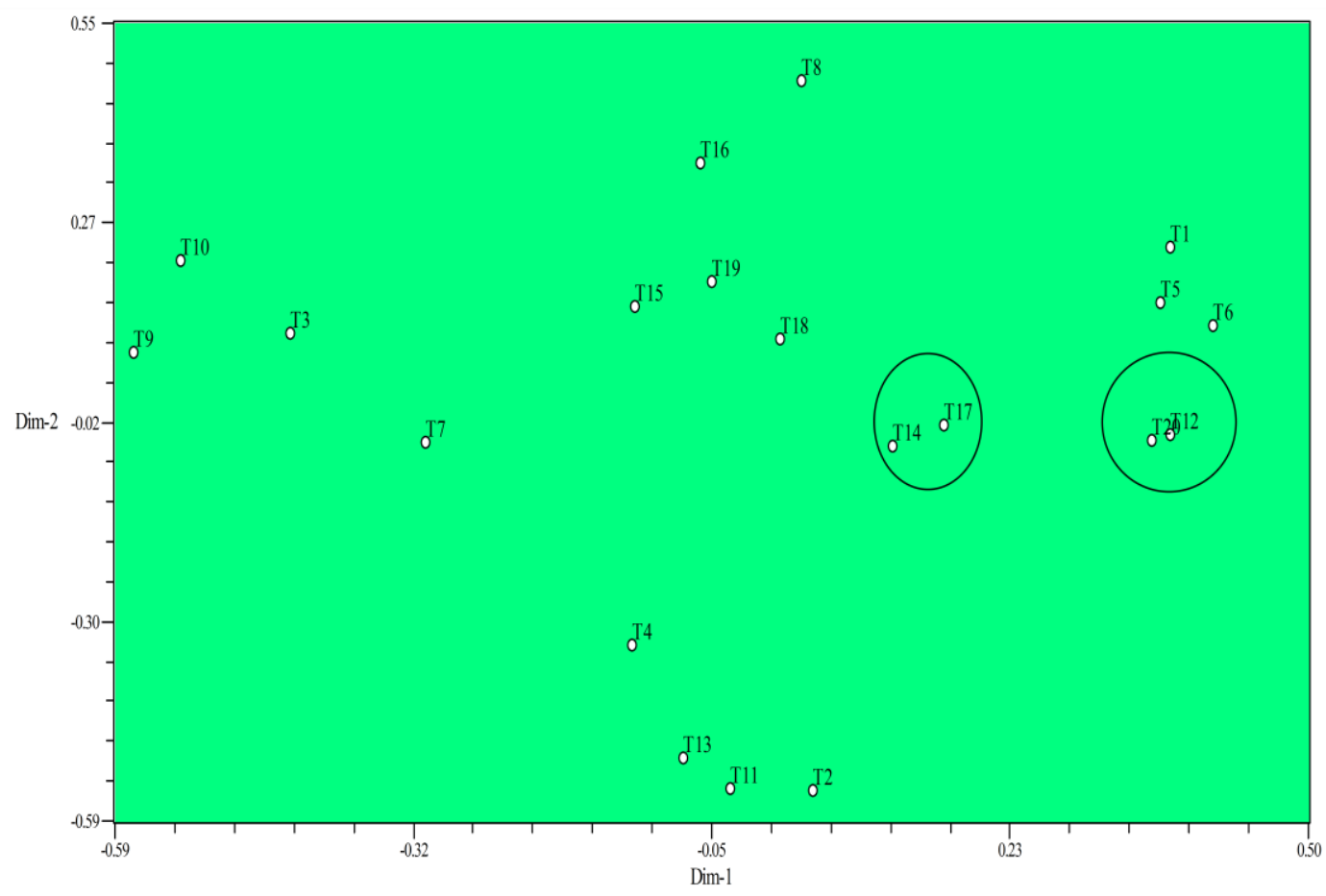

Figure 3 Two-dimensional scaling among Trichoderma isolates based on RAPD data

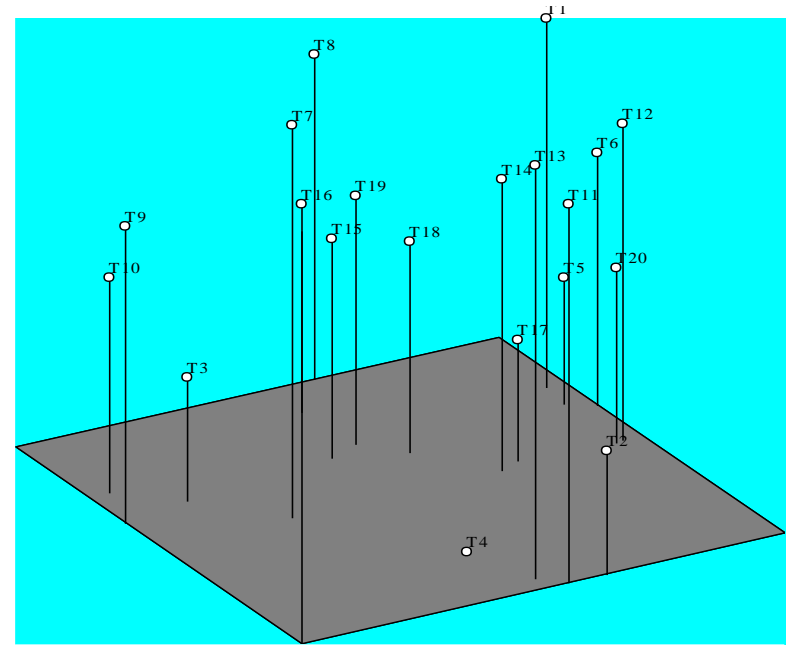

Figure 4 Three-dimensional scaling among Trichoderma isolates based on RAPD data

Trichoderma exhibited morphological and molecular variability. Molecular approach generated good information in respect of variability. In present study used RAPD markers were able to differentiate Trichoderma isolates in terms of diversity present among them. Isolates separated into two groups showed variability at genetic level.

\section{Acknowledgement}

The author is thankful to Dr. S.N. Singh, Head of the Department Plant Pathology, College of Agriculture, JNKVV, Jabalpur and Dr. P.K. Singh, Director of ICAR-DWR, Jabalpur, for providing the essential facilities necessary for conducting pathological and molecular part of my thesis work.

\section{Conflict of Interest}

Authors would hereby like to declare that there is no conflict of interests that could possibly arise.

\section{References}

Chakraborthy BN, Chakraborthy U, Saha A, Dey PL, Sunar K, (2010) Molecular characterization of Trichoderma viride and Trichoderma harzianum isolated from soils of North Bengal Based on rDNA markers and analysis of their PCR-RAPD profiles. Global Journal of Biotechnology and Biochemistry 5:55-61.

Dodd SL, Hill RA, Stewart A (2004) A duplex -PCR bioassay to detect Trichoderma virens biocontrol isolate in non-sterile soil. Soil Biology and Biochemistry 36:1955-1965.

Gams W, Bissett J (1998) Morphology and Identification of Trichoderma in Trichoderma and Gliocladium genus. Mycologia Research 100: 923-935. 
Rohalf FJ (2002) NTSYS-pc: numerical taxonomy system ver.2.1. Setauket (New York, USA): Exeter publishing.

Harman GE (2000) The myths and dogmas of biocontrol: changes in perceptions derived from research on Trichoderma harzariumm strain T-22. Plant Diseases 84:377-392.

Kuhls K, Lieckfeldt E, Samuels GJ, Borner T, Meyer W, Kubicek CP (1997) Revision of Trichoderma sect. Longibrachiatum including related teleomorphs based on analysis of ribosomal DNA internal transcribed spacer sequences. Mycologia 89:442-460.

Latha J, Verma A, Mukherjee PK (2002) PCR Fingerprinting of some Trichoderma isolates from two Indian type culture collections a need for re-identification of these economically important fungi. Current Science 83: 372-374.

Meyer W, Mitchell TG, Freedman EZ, Vilgalys R (1993) Hybridization probes for conventional DNA fingerprinting used as single primers in the polymerase chain reaction to distinguish strains of Cryptococcus neoformans. Journal of Clinical Microbiology 31: 2274-2280.

Miller J, Tanksley S (1990) RFLP analysis of phylogenetic relationships and genetic variation in the genus Lycopersicon. Theoretical Applied Genetics 80: 437-448.

Saghai-Maroof MA, Soliman KM, Jorgensen RA, Allard RW (1984) Ribosomal DNA spacer-length polymorphism in barley.
Mendelian inheritance, chromosomal location and population dynamics. Proceedings of National Academy of Science 81:8014-8018.

Sharma K, Mishra AK, Misra RS (2009) Morphological, Biochemical and Molecular Characterization of Trichoderma harzianum isolates for their efficacy as Biocontrol Agents. Phytopathology 157:51-56.

Sneath PHA, Sokal RR (1973) Numerical taxonomy: The principles and practice of numerical classification. San Francisco.

Singh US, Joshi BB (2007) Mass multiplication of Trichoderma harzianum on sugarcanepress mud. Indian Phytopathology 60:530-53.

Tomar A, Prasad L, Mishra A, Sagar S (2017) Antagonistic Action of Trichoderma Isolates against Fusarium oxysporum $f$. $s p$. Lycopersci. International Journal of Current Microbiology and Applied Sciences $6: 258-265$.

Tripathi N, Saini N, Tiwari S (2013) Morphological and molecular characterization of endangered medicinal plant species Coleus forskohlii collected from central India. Journal of Crop Science and Biotechnology 16: 253-261.

Williams JGK, Kubelik AR, Livak KJ, Rafalski JA, Tingey SV (1990) DNA polymorphisms amplified by arbitrary primers are useful as genetic markers. Nucleic Acid Research 18:6531-6535. 